\title{
SEDIMENTARY ENVIRONMENT OF THE EARLY PLEISTOCENE GRAVELS OF THE EDFU FORMATION FROM THE SAQQARA ARCHAEOLOGICAL SITE (EGYPT) - PRELIMINARY RESULTS
}

\author{
Anna Wysocka ${ }^{1}$, Fabian Welc ${ }^{2}$, Urszula Czarniecka ${ }^{3}$ \\ ${ }^{1}$ Faculty of Geology, University of Warsaw, Żwirki i Wigury 93, 02-089 Warsaw, anna.wysocka@uw.edu.pl \\ ${ }^{2}$ Institute of Archaeology, Cardinal StefanWyszyński Universityin Warsaw,f.welc@uksw.edu.pl \\ ${ }^{3}$ Institute of Geological Sciences, Polish Academy of Sciences, Twarda 51/55, 00-818 Warsaw, \\ u.czarniecka@twarda.pan.pl
}

\begin{abstract}
A gravel horizon is preserved in several locations within the world-wide known archaeological site in Saqqara (northern Egypt). It is characterized by a variable thickness, composed of coarse, quartz, quartzitic and flint pebbles, and considered to correspond to gravels of the Edfu Formation, deposited in the Early Pleistocene by the early phase of the Nile development (Protonile Phase). This relatively short (ca. $200 \mathrm{ka}$ ) and at the same time very dynamic period of Protonile activity during the Edfu Pluvial is one of the most poorly recognized hydrological-climatic episodes of the Quaternary in north-eastern Africa. This paper is focused on the preliminary sedimentological-petrographic characteristics of these deposits and an attempt to indicate their source areas as well as mechanisms of transportation and deposition in the context of Pleistocene pluvial episodes.
\end{abstract}

Key words: gravels, Edfu Pluvial, Pleistocene, Saqqara, Egipt.

Manuscript received 4 May 2015, accepted 12 February 2016

\section{INTRODUCTION}

Quaternary climatic changes in northern Africa are strictly related to the subsequent cold (glacials) and warm periods (interglacials) occurring in Europe and most of North America. They are recorded by alternating dry (interpluvials) and relatively humid intervals (pluvials). In effect, the evolution of the Nile valley also witnesses environmental changes that should be linked directly to global climatic changes (e.g. Zaki, 2007, Woodward et al., 2007, Welc and Marks, 2014). Till present, in north Africa, 7 pluvials have been distinguished, corresponding to global eustatic events (increase of global sea level) and warm phases (Said 1981). The chronologically oldest pluvials, i.e. the Edfu and Armant pluvials are dated as the Early Pleistocene. Because their successions are not separated by interpluvial deposits, the position of these pluvials in the stratigraphic scheme is not evident. The five subsequent pluvials, i.e. the Abbasia I, Abbasia II, Sahara I, Sahara II and Nabata pluvials, are assigned to the Middle - Late Pleistocene and the Early Holocene (cf., Said, 1990a, Wendorf et al., 1976, Schild and Wendorf, 2013).

The Early Pleistocene in the Egypt area was characterized by a remarkably dry climate, in effect vast dune fields developed, later reactivated in the Late Holocene, as for example the Sahara Desert. At the same time, the Late Pliocene river, i.e. the Palaeonile using the present-day Nile valley, ceased to flow to the north. This episode terminated with the encroachment of an extremely dynamic river from the south, i.e. the Protonile, during the Edfu Pluvial. Its presence is recorded by sediments which are difficult to date (ca. 1.86-1.5 $\mathrm{Ma}$ ), mainly gravels composed of quartz and quartzitic pebbles known as the Edfu Formation. The Protonile was relatively quickly succeeded by two subsequent rivers with a different and less dynamic regime, i.e. the Prenile and Neonile with characteristic gravel-sand deposits (Said, 1990a, 1993). The rather short (ca. $200 \mathrm{ka}$ ) but extremely dynamic period of Protonile activity during the Edfu Pluvial is evidently one of the least understood hydrological-climatic episodes in the Quaternary of north-eastern Africa.

A gravel horizon is preserved in several locations within one of the most well-known archaeological sites in Saqqara (northern Egypt). It is characterized by a variable thickness, composed of coarse pebbles built of quartz, quartzite and flint, and considered to correspond to the gravels of the Edfu Formation, deposited by the Protonile. This paper is focused on the preliminary sedimentological-petrographic characteristics of these deposits and an attempt to indicate their source areas as well as mechanisms of transportation and deposition in the context of Pleistocene pluvial episodes. 


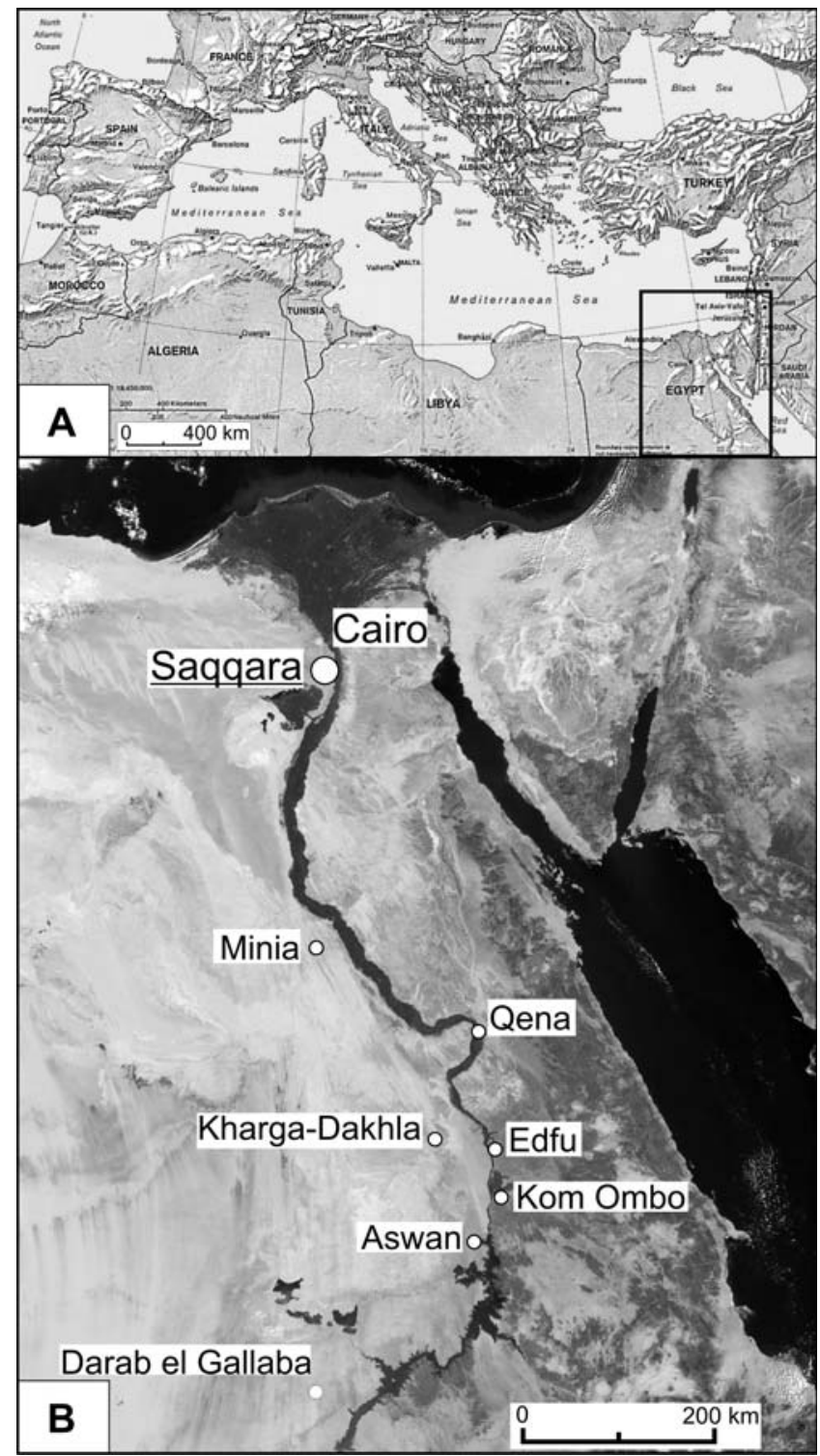

Fig. 1. A - The Mediterranean Sea area, rectangle - location of the study area; B - satellite map of Egypt, white points - occurrences of Edfu gravels noted in literature (based on Said, 1981).

\section{GEOLOGICAL SETTING}

The studies have been conducted in northern Egypt (Fig. 1A) within the Saqqara archaeological site. It is located on the west bank of the Nile, c. $15 \mathrm{~km}$ to the south-west of present-day Cairo $\left(29^{\circ} 52^{\prime} 13.27^{\prime \prime}, 31^{\circ} 13^{\prime} 02.23^{\prime \prime} \mathrm{E}\right)$ and is part of the vast Memphis Necropolis, which stretches out at a distance of over $70 \mathrm{~km}$ from Abu Rawash in the north to Medum near the Fayum oasis in the south (Fig. 1B). Morphologically, the area is a limestone plateau with height differences between several to over a dozen meters, dipping at c. $7^{\circ}$ to the west, with the eastern boundary of the area marked by a high cuesta separating the plateau from the floodplain of the present-day Nile lying somewhat below (for data on the geology of the Saqqara necropolis, cf. Youssef et al., 1984, Squyres et al., 1987, Klemm and Klemm, 2008, Klemm and Klemm, 2010, Welc, 2011, Welc et al., 2013, 2015, Welc and Trzciński, 2013).
In terms of regional geology, the area of northern Egypt is located within the North African Plate and is covered by deposits of variable lithology and origin. In this area Said (1962) distinguished four areas with a different geological setting and history: the Arabian-Nubian Shield (crystalline craton), a tectonically unstable area covering northern Egypt (unstable shelf), a tectonically stable area of southern Egypt (stable shelf) and the spreading area encompassing the Gulf of Suez and the Red Sea. The sedimentary cover includes an intermediate layer comprising Nubian sandstones of Palaeozoic age lying on the Precambrian crystalline core of the Arabian-Nubian Shield and the overlying platform cover composed of Mesozoic and Cenozoic carbonate and detritic rocks.

In the Late Miocene and Early Pliocene, the area of Egypt attained its final morphology, encompassing the continental area, the Red Sea, and the gulfs of Aqaba and Suez (Said, 1990). At that time the present-day orientation of the Nile valley was also established, with a delta and prodelta systematically expanding to the north. The Red Sea attained a direct connection with the Indian Ocean (Schlumberger, 1995).

The oldest fluvial system that may be described in the context of Nile evolution had developed in the area of Egypt already in the beginning of the Oligocene. However, the Nile valley was fully shaped not until the Late Miocene during the Messinian Crisis (Eonile phase) and attained a course similar to present-day (Said, 1990). Near Cairo, the Eonile valley bottom is located at the depth of $2.5 \mathrm{~km}$ and near Asuan - c. $700 \mathrm{~m}$ below the surface. In the Pliocene, a huge Eonile canyon was partly filled with deposits and gradually flooded by the rising waters of the Mediterranean Sea. Continuing climatic changes in the Late Pliocene caused the formation of the Palaeonile that used the old canyon of the Eonile (Said, 1990). Intense erosional processes removed part of the Pliocene sediments deposited in the canyon, thus exposing it upper margin, which from the west and east forms at present the monumental border of the present-day Nile (Sampsell, 2003).

Several phases of aggradation and erosion have been distinguished in the Quaternary of the Nile valley; they correspond to the Pleistocene phases of the Prenile and Protonile and the Holocene Neonile phase. In turn, the regime of the present-day Nile with its characteristic cyclic floodings was established not until the beginning of the Holocene, i.e. 12,500 years B.P. (Woodward et al., 2007). Quaternary deposits in present-day Egypt lie usually unconformably on the Pliocene or older strata. In desert areas, due to intensified erosion, they attain a small thickness and additionally are discontinuous, therefore their age determination is not evident. The Nile valley is filled with several series of Quaternary deposits, differing in texture and lithology. Each of these sequences developed as a result of a different fluvial system with diverse source areas.

The stratigraphy of the Late Neogene and Quaternary in Egypt is based on a sub-division into particular climatostratigraphic units corresponding to series of strata that were formed during subsequent pluvial episodes separated by interpluvials (Fig. 2) (Said, 1981). Additionally, it has been correlated with the palaeomagnetic scale for the Late Pliocene and Pleistocene (Fig. 2). In Egypt, the pluvial episodes are mainly represented by deluvial and lacustrine (playa) deposits as well as palaeosols. The interpluvials are documented by 
eolian and evaporitic sediments. At present, 6 main pluvials are distinguished in the Quaternary. The two oldest ones, i.e. the Edfu and Armant pluvials, are Early Pleistocene in age. So far, their stratigraphic position has not been confirmed and it is not clear which sediments exactly record these pluvials. In a later episode, the Protonile was succeeded by two subsequent rivers with a much lower flow regime, i.e. the Prenile and Neonile, whose deposits differ significantly (Said, 1993).

\section{METHODS OF STUDY}

The field study was conducted within the Saqqara archaeological site, where gravels were observed in numerous localities, i.e. directly on the surface or in archaeological excavations (Fig. 3A). The best exposures for study are located in the southern wall of the Dry Moat, i.e. a deep rock-hewn ditch lying over a dozen metres to the north of the base of the Unas Pyramid (for data on the Dry Moat, cf. Herbich and Jagodziński, 1988, Swelim, 1988, 1991, 2006, Myśliwiec, 2006) (point 2 in Fig. 3A; Figs 3B, 4A) as well as on the surface of a ritual altar preserved in the northern part of the Step Pyramid of Pharaoh Djoser (point 4 in Fig. 3A and Fig. 3C). The gravels are also exposed in cross-sections of numerous funeral constructions (e.g. near the Unas Pyramid, Fig. 3D) or directly below the foundations of the Step Pyramid (e.g. point 3 near the southern entrance to the Pyramid, Fig. 3A, E). Standard lithological-sedimentological descriptions were made in points 2 and 4 (for lacation see Fig. 3A). Additionally, the maximum particle size (MPS) was determined for three measurement sites in the Dry Moat, according to the methodology proposed by Nemec and Steel (1984). Initial petrographic analysis of the pebbles from the coarsest fraction ( $>4 \mathrm{~cm}, 2-4 \mathrm{~cm}$ ) was made directly in the field. Quartz, plutonic rocks, rocks with a porphyry structure, basalts, flints and sedimentary rocks have been recognized. The analysis was made for 4 samples collected directly from the exposure, each for at least 50 pebbles (Fig. 5D, E) (methodology after Mycielska-Dowgiałło and Rutkowski, 1995). Additionally, smaller samples of the finer fraction $(<2 \mathrm{~cm})$, representing the gravel matrix, were collected from each sample for further laboratory analyses (Fig. 5C).

Dried and fragmented matrix samples from the analysed gravels with a sample weight of $100 \mathrm{~g}$ were sieved on a sieve column. To determine the contribution of particular fractions in the entire deposit, the residue from each sieve was weighed and parameters of grain size distribution were determined using the graphic method (Folk and Ward, 1957): mean diameter (Mz), standard deviation (ó) and skewness (Sk). Next, using an optical microscope, the petrographic composition of $0.5-1 \mathrm{~mm}$ and $1--2 \mathrm{~mm}$ fractions was conducted and five lithological-mineral groups were distinguished: quartz, quartz sandstones and siltstones, limestones, crystalline rocks and dark minerals.

The next step was to determine the content of carbonates. Grain material representing $0.1-0.25 \mathrm{~mm}, 0.25-0.5 \mathrm{~mm}$ and $0.5-1 \mathrm{~mm}$ fractions was inserted in $20 \%$ hydrochloric acid. Undissolved residue was irrigated several times with distilled water, dried and weighed.

Degree of rounding and character of quartz grain surfaces was also analysed. Grains representing $0.25-0.5 \mathrm{~mm}$

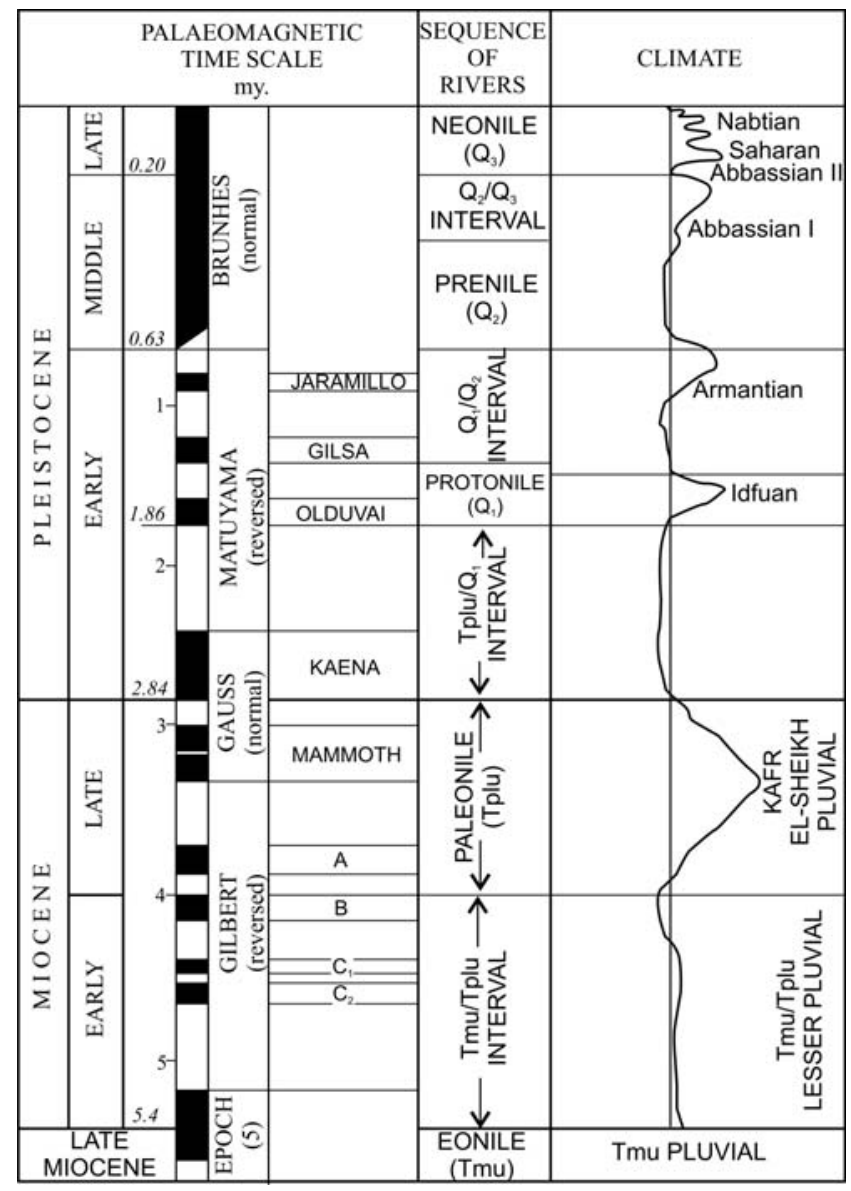

Fig. 2. Phases of Nile evolution correlated with the palaeomagnetic scale and climatic events (after Said, 1981).

and $0.5-1 \mathrm{~mm}$ fractions were viewed in an optical microscope and next, based on the morphoscopic classification of quartz grains by Cailleux (1942) with later modifications (e.g., Goździk, 1980, Mycielska-Dowgiałło, 1995, Mycielska-Dowgiałło and Woronko, 1998).

\section{LITHOLOGY AND FRAMEWORK OF THE GRAVELS}

Gravels of the Edfu Formation in Saqqara represent a complex of coarse gravels/gravelstones with a variable thickness, maximally up to $1.5-2.0 \mathrm{~m}$, and degree of lithification. They lie on an uneven erosional surface developed in the top of Upper Eocene carbonate and marly deposits (cf., Welc and Trzciński, 2013) (Fig. 4A, B). The largest exposure of these sediments, over $100 \mathrm{~m}$ long and 3-4 m high, is preserved near the northern base of the Unas Pyramid (point 2 in Fig. 3A, and Figs 3B, 4A). The thick and continuous gravel cover extends there along the southern margin of the Dry Moat, which is a monumental ditch of variable thickness, rock-hewn during the early Old Kingdom times (ca. 4600 B.P.) and surrounding the Step Pyramid from all sides.

The exposed gravels are massive and coarse with a maximum particle size between $8.65-10.46 \mathrm{~cm}$. The contribution of the sandy matrix between the pebbles is also variable. The gravels are often densely packed, grain-to-grain contacts dominate, the grain framework is dense and they are clast-su- 

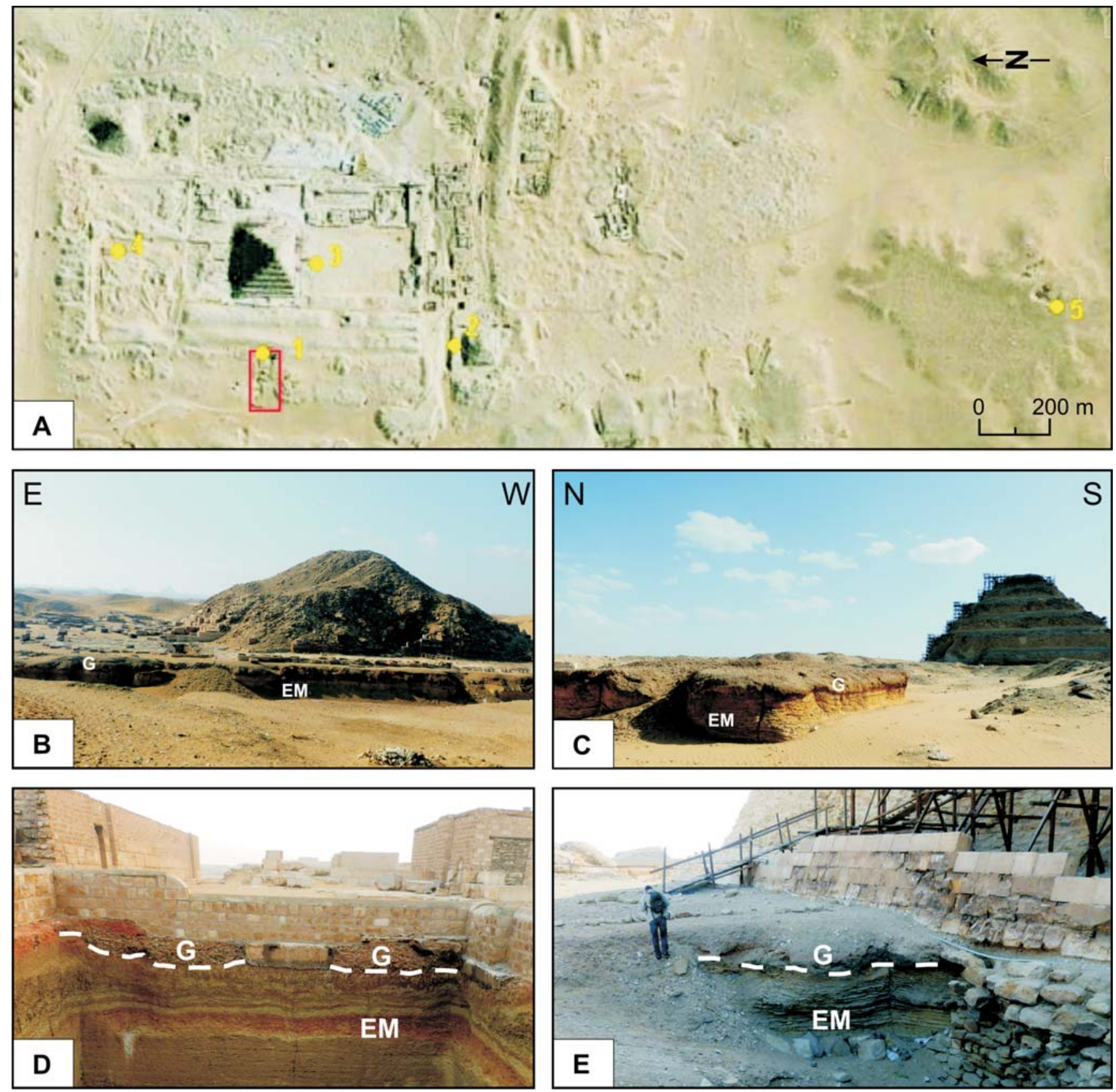

Fig. 3. A-Area of the archaeological site in Saqqara, 1-5 points with gravel (G) occurrence (G) lying directly on older marly deposits of Eocene age (EM); B - view from the north towards the Unas Pyramid (point 2 in Fig. 3A), the Dry Moat is visible in the foreground; $\mathbf{C}-$ view from the north-west towards the Step Pyramid of Pharaoh Djoser (point 4 in Fig. 3A), the stipe of the ritual altar hewn in gravels and Eocene marls is visible in the foreground; D - funeral shaft in the courtyard near the eastern corner of the Unas Pyramid (point 2 in Fig. 3A), note uneven erosional top of the marls with gravels lying above; $\mathbf{E}$ - southern courtyard of the Step Pyramid of Pharaoh Djoser (point 3 in Fig. 3A), note gravel cover lying on Eocene marls.

pported (Figs 4B, 5A), whereas in other parts the matrix contribution is high, particular pebbles do not contact and the matrix is dispersed, sand-supported (Figs 4C, 5B). Such texture of gravels is typical of alluvial and fluvial settings (e.g., Nemec and Steel, 1984, Blair and McPherson, 1994). The massive structure of the sediment, occurrence of a continuous gravel cover within the entire study area suggests deposition of a high-energy bedded flooding. In effect, parts of the sediment subject to rapid deposition have a dispersed grain framework, whereas those, where intense washing out of the finer fraction took place, have a densely packed framework. Such deposition could have taken place within a large-scale depositional form, i.e. an alluvial fan, or a gravel cover of flood deposits related to extremely intense floods (e.g., Miall, 1978, Nemec and Steel, 1984, Blair and McPherson, 1994, Nichols and Hirst, 1998). It should be pointed out that precise determination of the sedimentary conditions of the analysed deposits requires a wider research including also other exposures of gravel covers of the Edfu Formation in central and southern Egypt (Fig. 1B). 

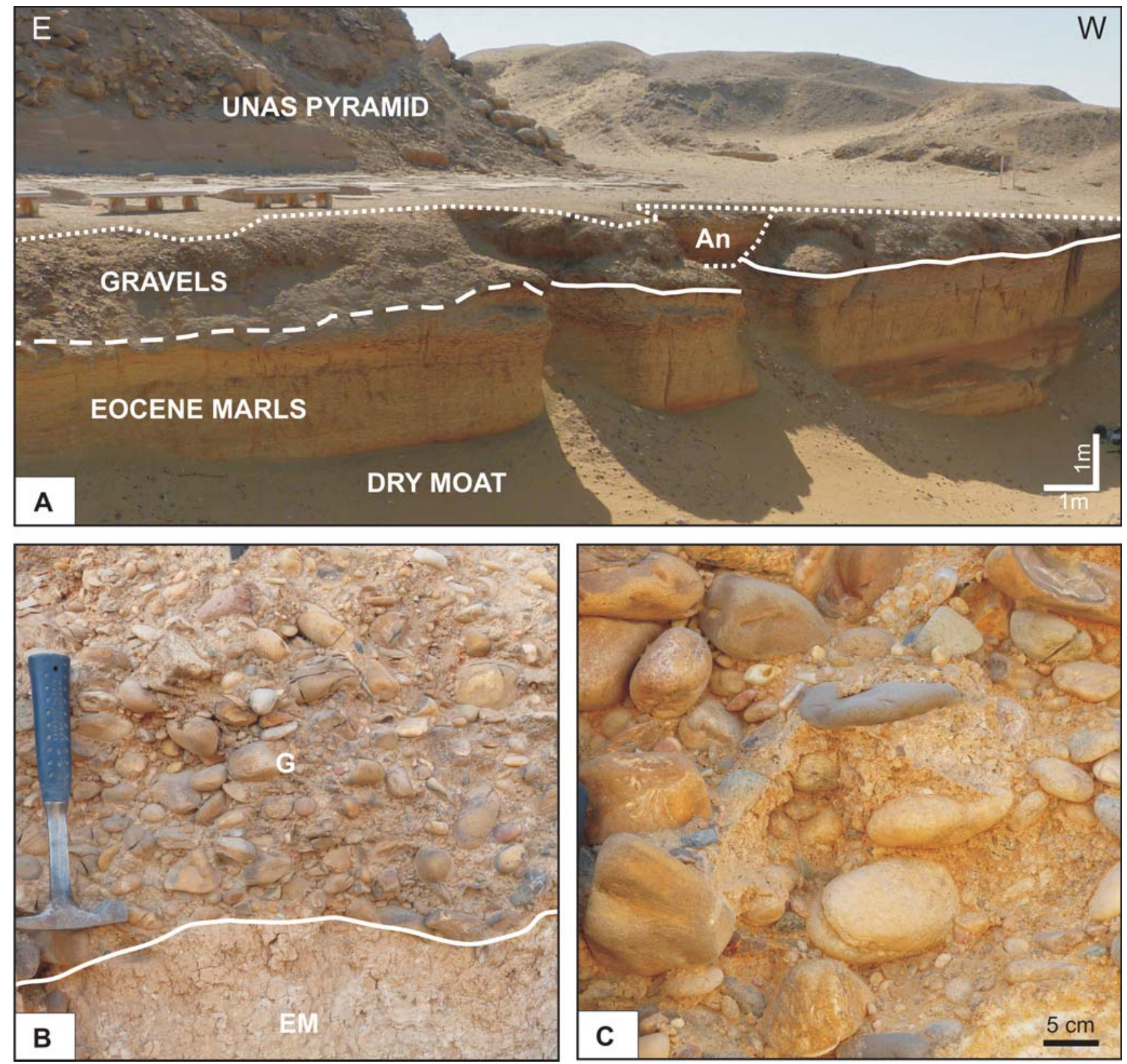

Fig. 4. A-Northern wall of the Dry Moat at the base of the Unas Pyramid, built of Eocene marls and covered with gravels, incised by anthropogenic excavations (An). Note uneven erosional top of the marls; the top of the gravels is an artificially levelled anthropogenic surface; $\mathbf{B}$ - close-up of the erosional contact of marls (EM) and gravels $(\mathrm{G}) ; \mathbf{C}$ - poorly selected coarse gravels with variable matrix, from matrix-supported to grain-supported.

\section{Composition of the grain framework}

The following mineral-lithological groups were distinguished based on the macroscopic petrographic analysis of the grain framework: quartz, plutonic rocks, rocks with a porphyry texture, basalts, flints and sedimentary rocks (Fig. $5 \mathrm{E})$. Fraction $>4 \mathrm{~cm}$ in all samples is dominated by black and brown flints. Pebbles of quartz, plutonic and volcanic rocks and sedimentary rocks occur in subordinate amounts. Fraction $2-4 \mathrm{~cm}$ is characterized by a decreased amount of flints, although they still are the dominant group. In turn, the percentage content of quartz and plutonic pebbles increases.

\section{Grain size and petrographic composition of the matrix}

Based on sieve analysis of the matrix from the analysed samples, parameters of grain-size distribution were determined (Tab. 1). The average grain size (Mz) corresponds to medium sand (samples nos. 3,4 ) or very coarse sand (samples nos. 1, 2). Standard deviation (ä) indicates poor (samples nos. $2,3,4$ ) or very poor (sample no. 1) selection of the grain material. Skewness (Sk) values usually correspond to very positive (samples nos. 1, 4) or positive values (sample no. 2), suggesting enrichment in finer fractions. Concluding, the obtained parameters of grain-size distribution (Tab. 1) indicate 
Table 1

Results of laboratory analyses of the Saqqara gravels

\begin{tabular}{|c|c|c|c|c|c|c|c|c|c|c|c|}
\hline \multirow{2}{*}{ No. } & \multirow{2}{*}{$\begin{array}{l}\text { grain size } \\
\text { parameters }\end{array}$} & \multicolumn{3}{|c|}{$\begin{array}{l}\text { petrographic composition } \\
\text { of the matrix }[\%]\end{array}$} & \multicolumn{3}{|c|}{$\begin{array}{c}\text { quartz grain micromorphology } \\
{[\%]}\end{array}$} & \multicolumn{4}{|c|}{$\begin{array}{c}\text { ratio of carbonate to non-carbonate elements } \\
{[\%]}\end{array}$} \\
\hline & & grain & $\begin{array}{c}1.0-2.0 \\
\mathrm{~mm}\end{array}$ & $\begin{array}{c}0.5-1.0 \\
\mathrm{~mm}\end{array}$ & grain & $\begin{array}{c}1.0-2.0 \\
\mathrm{~mm}\end{array}$ & $\begin{array}{c}0.5-1.0 \\
\mathrm{~mm}\end{array}$ & grain & $\begin{array}{c}0.5-1.0 \\
\mathrm{~mm}\end{array}$ & $\begin{array}{c}0.25-0.5 \\
\mathrm{~mm}\end{array}$ & $\begin{array}{c}0.1-0.25 \\
\mathrm{~mm}\end{array}$ \\
\hline \multirow{8}{*}{1} & & & & & $\mathrm{RM}$ & 16.5 & 18 & & & & \\
\hline & & & & & EL & 22 & 33.5 & & & & \\
\hline & & Q & 32 & 35 & EM & 20.5 & 25.5 & & & & \\
\hline & $\mathrm{Mz}-0.70$ & $\mathrm{~S}$ & 3 & 65 & $\mathrm{EM} / \mathrm{EL}$ & 14.5 & 9.5 & $\mathrm{NC}$ & 51.8 & 43.2 & 10.9 \\
\hline & $\delta 2.34$ & $\mathrm{~L}$ & 54 & 0 & EM/RM & 21 & 8.5 & $\mathrm{C}$ & 48.2 & 56.8 & 89.1 \\
\hline & Sk 0.34 & $\mathrm{P}$ & 11 & 0 & $\mathrm{EL} / \mathrm{C}$ & 5.5 & 5 & & & & \\
\hline & & $\mathrm{DM}$ & 0 & 0 & $\mathrm{~L}$ & 42 & 48 & & & & \\
\hline & & & & & $\mathrm{M}$ & 58 & 52 & & & & \\
\hline \multirow{8}{*}{2} & & & & & $\mathrm{RM}$ & 10 & 20 & & & & \\
\hline & & & & & EL & 15 & 22.5 & & & & \\
\hline & & Q & 42 & 48 & EM & 14.5 & 20.5 & & & & \\
\hline & Mz - 0.96 & $\mathrm{~S}$ & 11 & 39 & EM/EL & 36.5 & 24 & $\mathrm{NC}$ & 91.1 & 79.1 & 33.1 \\
\hline & $\delta 1.93$ & $\mathrm{~L}$ & 0 & 0 & EM/RM & 19.5 & 9.5 & $\mathrm{C}$ & 8.9 & 20.9 & 66.9 \\
\hline & Sk 0.16 & $\mathrm{P}$ & 47 & 13 & $\mathrm{EL} / \mathrm{C}$ & 4.5 & 3.5 & & & & \\
\hline & & $\mathrm{DM}$ & 0 & 0 & L & 56 & 50 & & & & \\
\hline & & & & & $\mathrm{M}$ & 44 & 50 & & & & \\
\hline \multirow{8}{*}{3} & & & & & $\mathrm{RM}$ & 14.5 & 4 & & & & \\
\hline & & & & & EL & 13 & 24 & & & & \\
\hline & & Q & 39 & 94 & EM & 51.5 & 20 & & & & \\
\hline & Mz 1.66 & $\mathrm{~S}$ & 9 & 6 & $\mathrm{EM} / \mathrm{EL}$ & 10.5 & 31.5 & $\mathrm{NC}$ & 96.1 & 97.3 & 83.1 \\
\hline & $\delta ? 1.2$ & $\mathrm{~L}$ & 0 & 0 & EM/RM & 8 & 16 & $\mathrm{C}$ & 3.9 & 2.7 & 16.9 \\
\hline & Sk -0.11 & $\mathrm{P}$ & 50 & 0 & $\mathrm{EL} / \mathrm{C}$ & 2.5 & 4.5 & & & & \\
\hline & & $\mathrm{DM}$ & 2 & 0 & $\mathrm{~L}$ & 26 & 60 & & & & \\
\hline & & & & & $\mathrm{M}$ & 74 & 40 & & & & \\
\hline \multirow{8}{*}{4} & & & & & $\mathrm{RM}$ & 19 & 15 & & & & \\
\hline & & & & & EL & 23.5 & 34 & & & & \\
\hline & & Q & 70 & 88 & EM & 39 & 23.5 & & & & \\
\hline & Mz 1.25 & $\mathrm{~S}$ & 9 & 8 & $\mathrm{EM} / \mathrm{EL}$ & 9.5 & 14.5 & $\mathrm{NC}$ & 96.2 & 97.4 & 84.1 \\
\hline & $\delta 1.13$ & $\mathrm{~L}$ & 0 & 4 & $\mathrm{EM} / \mathrm{RM}$ & 7.5 & 9 & $\mathrm{C}$ & 3.8 & 2.6 & 15.9 \\
\hline & Sk 0.35 & $\mathrm{P}$ & 21 & 0 & $\mathrm{EL} / \mathrm{C}$ & 1.5 & 4 & & & & \\
\hline & & $\mathrm{DM}$ & 0 & 0 & $\mathrm{~L}$ & 34.5 & 52.5 & & & & \\
\hline & & & & & $M$ & 65.5 & 47.5 & & & & \\
\hline
\end{tabular}

very coarse sand. The value of standard deviation points to very poor selection of the studied material, whereas skewness indicates very positive values, which indicates significant enrichment of the sediment in finer fractions. Such grain-size distribution may indirectly evidence deposition in a zone with variable but generally high energy of the transporting medium, relative proximity of the source area and/or relatively short transportation.

Grains from fractions $0.5-1.0 \mathrm{~mm}$ and $1.0-2.0 \mathrm{~mm}$ were subject to analysis of petrographic composition (Tab. 1, Fig. $\left.5 E^{\prime}\right)$. The following main groups have been distinguished: quartz (Q), lithoclasts of sandstones and siltstones (S), lithoclasts of plutonic rocks $(\mathrm{P})$ and lithoclasts of carbonate rocks (L) (Fig. 5E' and Tab. 1). Dark minerals (DM) occur in one of the samples in trace amounts. The conducted analysis shows that fraction $1.0-2.0 \mathrm{~mm}$ is characterized by grains with higher lithological variability than fraction $0.5-1.0 \mathrm{~mm}$.
Moreover, the content of lithoclasts of plutonic rocks decreases with smaller grain size. At the same time the content of quartz grains increases, which may be linked with the erosion of plutonic rocks mentioned above. An opposite trend occurs in the case of lithoclasts of sandstones and siltstones, i.e. their content usually increases with decrease of grain size. Likewise, the content of carbonate lithoclasts usually increases with decrease of grain size (Tab. 1). However, it should be noted that the values given in the table do not indicate the contribution or the ratio of the carbonate to non-carbonate grains, but the ratio of all carbonate to non-carbonate elements of the rock, owing to the fact that the samples contain a significantly high amount of lithoclasts of quartz sandstones and siltstones with a calcareous matrix.

Comparison of the composition of the grain framework and the matrix in the analysed gravels clearly indicates a diverse composition of the gravel- and sand-size grains. In the 

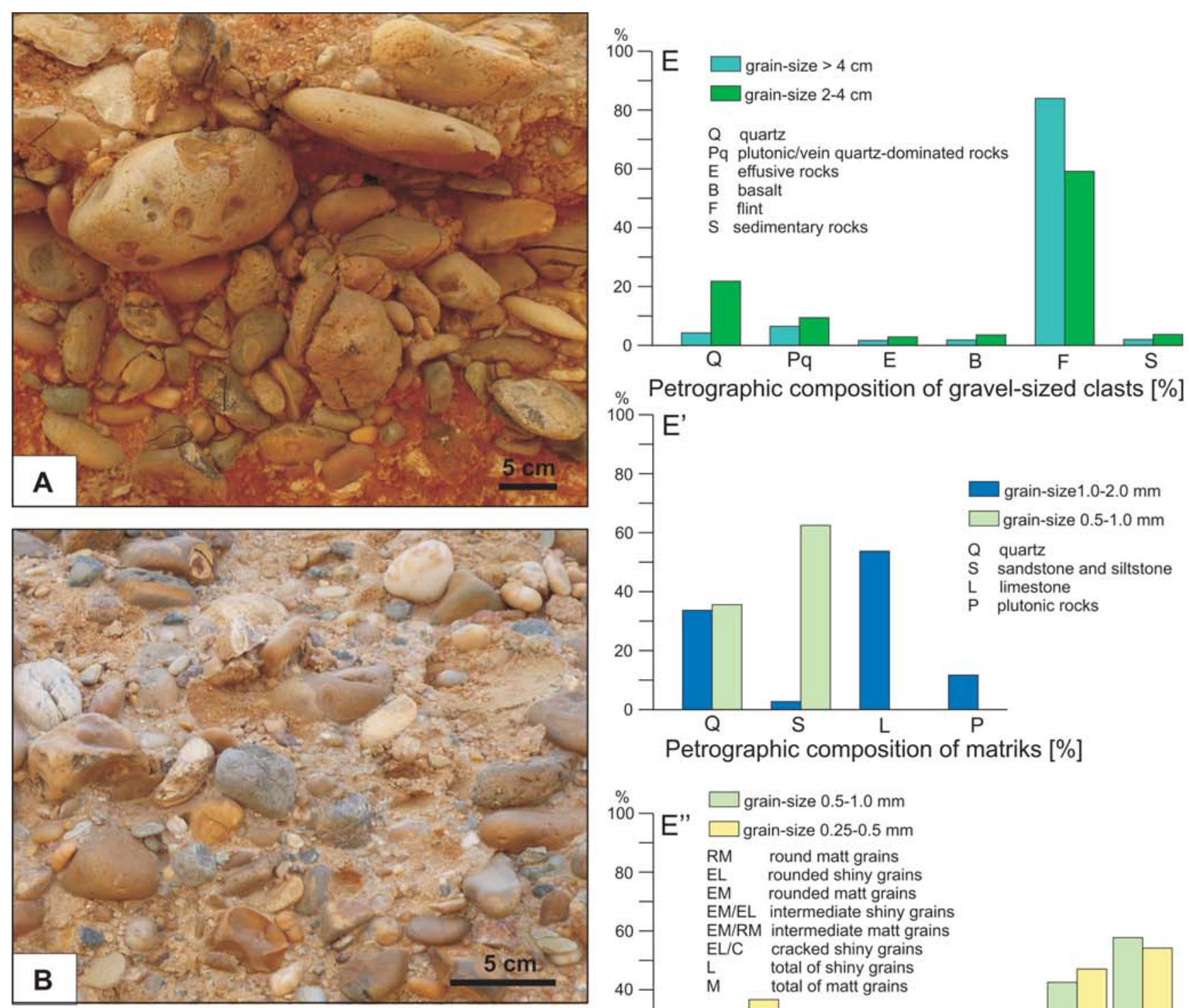

Petrographic composition of matriks [\%]
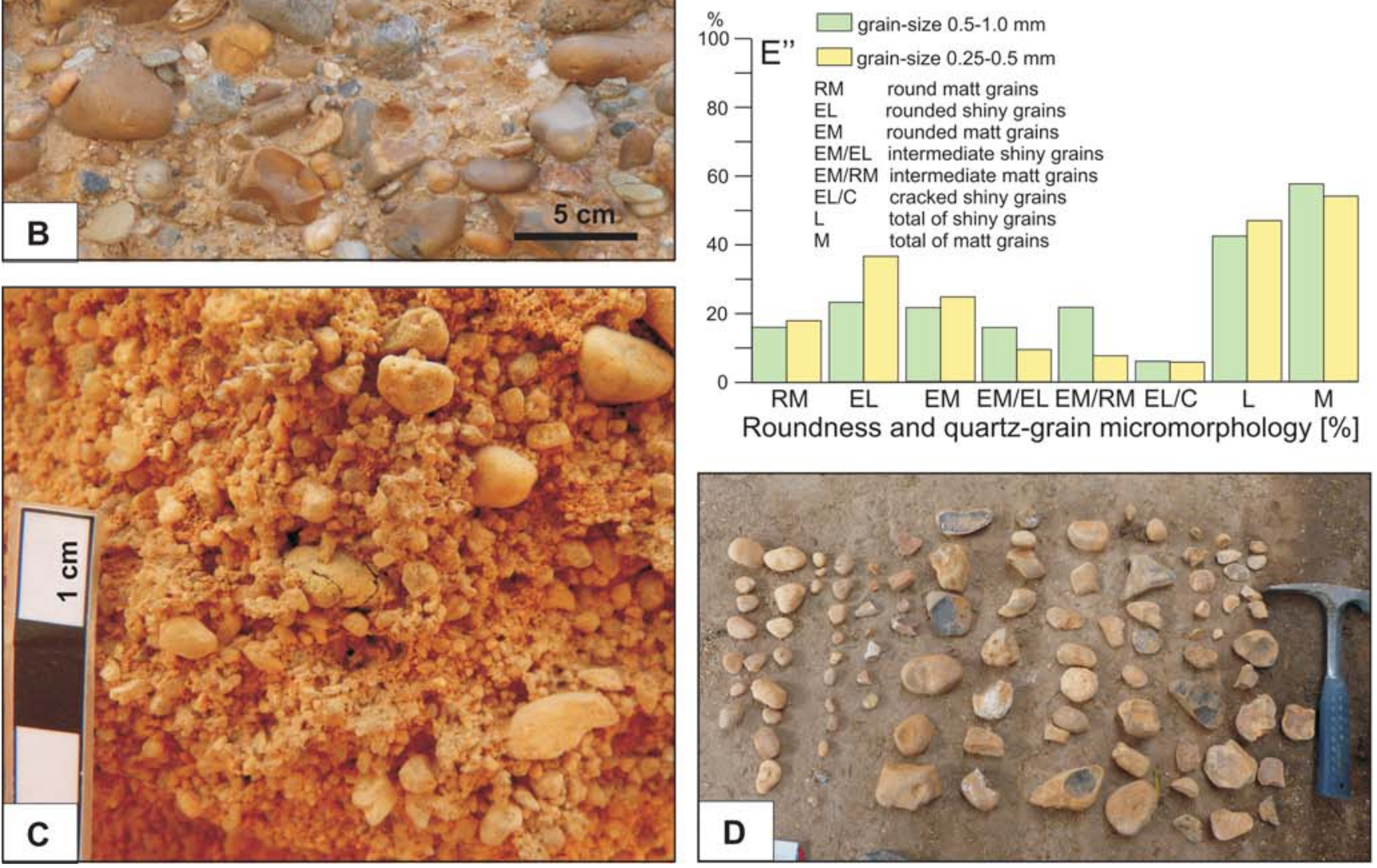

Fig. 5. Characteristics of gravels from the Saqqara archaeological site: $\mathbf{A}$-coarse gravels with dispersed, sandy grain framework; $\mathbf{B}-$ medium gravels with dispersed, sandy grain framework; C - close-up of sandy-fine-gravel matrix from gravels with dispersed framework; D gravels sample subject to macroscopic assessment of petrographic composition; E-E" - collective analyses for the Saqqara gravels: diagrams of petrographic composition of the grain framework (E), petrographic composition of the sandy matrix (E') and analysis of the degree of rounding and grain surface character of quartz grains from the matrix (E'). 
grain framework, the gravel fraction is dominated by flint pebbles, whereas in the matrix prevail quartz and lithoclasts of various sedimentary rocks in the sand fraction. Such bimodality of grain composition in the studied gavels may result from a twofold source of the grain material as well as different distances to the source areas. Most probably, material composing the matrix of the studied gravels derives from a more distant source area than the large grains of the grain framework $(>2 \mathrm{~cm})$. This issue requires further studies and comparisons to the composition of gravels from the Edfu Formation, whose exposures are located not only in southern Egypt but also in Nubia (Fig. 1B).

\section{Rounding and character of the quartz grain surfaces from the gravel matrix}

The degree of rounding and character of their surfaces were analysed in quartz grains representing fractions $0.5-1.0$ $\mathrm{mm}$ and 1.0-2.0 $\mathrm{mm}$ (Tab. 1 and Fig. 5E"). Based on the morphoscopic analysis of quartz grains after Cailleux (1942) with later modifications (e.g.: Goździk, 1980, MycielskaDowgiałło, 1995, Mycielska-Dowgiałło and Woronko, 1998), the following groups were distinguished: round matt grains $(\mathrm{RM})$, rounded shiny grains (EL), rounded matt grains (EM), intermediate shiny grains (EM/EL), intermediate matt grains $(\mathrm{EM} / \mathrm{RM})$ and cracked shiny grains $(\mathrm{EL} / \mathrm{C})$. Regardless the fraction, the grain types are highly diverse in the analysed samples. Matt grains usually prevail $(\mathrm{RM}+\mathrm{EM}+\mathrm{EM} / \mathrm{RM})$, and their origin is linked with an eolian setting (Woronko, 2001, Mycielska-Dowgiałło and Woronko, 2004). Matting of the grain surfaces may also result from intense processes of chemical weathering taking place e.g. in warm climate (Mycielska-Dowgiałło, 1995). Moreover, high contribution of shiny grains, mainly EL and EM/EL, indicates deposition in an aqueous, fluvial or near shore setting (Woronko, 2001, Woronko and Bujak, 2010). The degree of rounding is usually good (EL+EM) or very good, indirectly pointing to the high energy of the transporting environment and/or large distance to the source area.

\section{DISCUSSION AND CONCLUSIONS}

Gravels of the Edfu Formation in Saqqara are represented by coarse gravels with dense or dispersed grain framework and sand matrix. The pebbles are dominated by flints, whereas the matrix - by quartz and lithic grains. Composition of the grain framework and the matrix are different, which may indicate at least two sources of the grain material located at different distances from the depositional area. The sediments were transported over large distances in a high-energy setting and deposited within a vast alluvial fan or, which is more probable, within a vast gravel flood cover of fluvial origin.

As mentioned above, the Saqqara gravels are traditionally assigned to the Edfu Formation. However, this formation is not well defined with regard to its mineralogical-lithological composition (Shukri and Azer, 1952) or textural features.

Numerous sites with similar gravel deposits have been described from many localities in Egypt and Nubia, however, their stratigraphic position, origin and relations to the subsequent stages of Nile development remain unclear. The most complete successions of the Edfu Formation occur near Kom Ombo on the western bank of the Nile. They were subject to intense exploitation in Wadi Qura. They were documented on the western bank of the Nile between Kom Ombo and Esna and in the vicinity of Minia, where they fill a palaeochannel running at c. $10-15 \mathrm{~km}$ from the present-day Nile to Cairo. Further to the north the remains of the Protonile were noted in Abu Rawash. Some remnants of the Protonile palaeochannel were noted also to the west of Rosetta (Said, 1981).

In Nubia, the area of Darab el Gallaba is almost completely covered by these deposits. They are eroded in many places and their thickness is variable. In some localities they must have occurred $30 \mathrm{~m}$ above their present-day position, i.e. 50-60 $\mathrm{m}$ above the level of present-day Nile. Studies have shown that the deposits near Darab el Gallaba are the remains of a flat-bottom flood valley of a very dynamic braided river that transported mainly gravels in a wide channel encompassing a system of side streams (Said, 1981).

Issawi (1983) described in other localities in Nubia similar gravel covers that should probably also be linked with Protonile activity. They were located at the level of 32 and 21 $m$ above the Nile flood terrace prior to the construction of the Aswan Dam. Terraces with gravels were also noted in Wadi Korosko (23-25 m) and Dakka (30-35 m). These gravel successions are composed of quartz pebbles in a clay matrix, with thicknesses not exceeding $7 \mathrm{~m}$. Another gravel variation, known as the Early Nile Gravel, is represented by coarse gravels near Aswan in the Dihmit (44-48 m) and Adindan sites (23-25 m), composed of cobbles reaching a diameter of $10-20 \mathrm{~cm}$, dominated by quartz. Thus, with regard to the composition of the grain framework and textural features they are similar to the analysed Saqqara gravels. However, the distance between these sites (over $400 \mathrm{~km}$ in a straight line) and lack of detailed data on their composition allow only a provisional determination of their similarity (Said, 1981).

Summing up, gravels of the Edfu Formation differ significantly from the younger gravels of the Armant Formation, because they contain pebbles from non-local sources that must have been transported from a very distance source and are much smaller in comparison to the gravels of the Armant Formation. However, the existing descriptions do not allow credible and clear-cut correlations without a wide regional context, detailed analysis of textural features and composition, tracking alternations and variability. So far, very scanty geological data allow for a few general conclusions, according to which the gravels of the Edfu Formation should be assigned to the oldest Quaternary deposits in the Nile valley in Egypt and northern Sudan (Nubia). The gravels were deposited by a river with very dynamic flow regime, known as the Protonile. This river flew in the Nile valley in the Early Pleistocene, during a notably humid interval known as the Edfu Pluvial for about 200,000 years. The relatively simple petrographic composition of these deposits indicates that the material is derived from a relatively distant source area, but probably located within the area of Egypt and Sudan. In its lower reach, the river successively incorporated local material into its transported load, a fact that is testified by studies of the Edfu Formation in Saqqara. Further studies and 
field analyses of the Edfu Formation in a wider geographic range should be initiated in the future to enrich knowledge on one of the more important and at the same time poorly known hydrological-climatic episode of north-eastern Africa, i.e. the Edfu Pluvial.

\section{Acknowledgements}

The authors would like to offer grateful thanks to all participants of the Archaeological Mission 2014 in Saqqara, particularly to the Mission Director, Professor Karol Myśliwiec, for the possibility of conducting geological studies during the archaeological mission.

\section{REFERENCES}

Blair, T.C., McPherson, J.G., 1994. Alluvial fans and their natural distinction from rivers based on morphology, hydraulic processes, sedimentary processes, and facies assemblages. Journal of Sedimentary Research A64, 450-489.

Cailleux, A., 1942. Les actiones éoliennes périglaciaires en Europe. Mm. Soc. Géol. de France 41, 1-176.

Folk, R.L., Ward, W.C., 1957. Bravos river bar: a study in the significance of grain size parameters. Journal of Sedimentary Petrology 27 (1), 3-26.

Goździk, J., 1980. Application of morphometry and graniphormametry in the study of deposits from the brown coal mine in Bełchatów (Zastosowanie morfometrii i graniformametrii do badań osadów w kopalni węgla brunatnego Bełchatów). Studia Regionalne 4 (9), 101-114 (in Polish).

Herbich, T., Jagodziński, A., 1988. Geophysical investigation of the Dry Moat of the Netjerykhet complex in Saqqara. In Sulgowska, Z., Tomaszewski, A.J. (eds) Man-Millennia-Environment. Studies in honour of Romuald Schild, 273-279. Institute of Archaeology and Ethnology, Polish Academy of Sciences. Warszawa.

Issawi, B., 1983. Ancient Rivers of the Eastern Egyptian Desert. Episodes 2, 3-6.

Klemm, D., Klemm, R., 2010. The stones of the pyramids, provenance of the building stones of the Old Kingdom Pyramids of Egypt. Walter de Gruyter: Berlin - New York, 12-26.

Klemm, R., Klemm, D., 2008. Stones and quarries in Ancient Egypt. The British Museum Press: London, 40-57.

Miall, A.D., 1978. Lithofacies types and vertical profile models in braided river deposits: a summary. In Miall, A.D. (ed.) Fluvial Sedimentology, Canadian Society of Petroleum Geology Memoirs 5, 597-604.

Mycielska-Dowgiałło, E., 1995. Selected textural properties of sediments and their interpretational value (Wybrane cechy teksturalne osadów i ich wartość interpretacyjna). In Mycielska-Dowgiałło, E., Rutkowski, J. (eds) Badania osadów czwartorzędowych. Wybrane metody i interpretacja wyników, 29-105. WGiSR UW, Warszawa (in Polish).

Mycielska-Dowgiałło, E., Rutkowski, J., 1995. Studies of Quaternary sediments. Selected methods and interpretation of results (Badania osadów czwartorzędowych. Wybrane metody i interpretacja wyników). WGiSR UW, Warszawa (in Polish).

Mycielska-Dowgiałło, E., Woronko, B., 1998. Analysis of rounding and matting on surfaces of quartz grains in the sand fraction and its interpretational value. Przegląd Geologiczny 46, 1275-1281 (in Polish with English summary).

Mycielska-Dowgiałło, E., Woronko, B., 2004. The degree of aeolization of Quaternary deposits in Poland as a tool for stratigraphic interpretation. Sedimentary Geology 168, 149-163.

Myśliwiec, K., 2006. The Dry Moat west of the Netjerykhet enclosure. In Barta, M. (ed.) The Old Kingdom Art and Archaeol- ogy, pp. 233. Proceedings of the conference held in Prague, Maj 31 - June 4, 2004. Prague.

Nemec, W., Steel, R., 1984. Alluvial and coastal conglomerates: their significant features and some comments on gravelly mass-flow deposits. In Koster, E.H., Steel, R. (eds) Sedimentology of Gravels and Conglomerates, 1-31. Canadian Society of Petroleum Geologists Mem. 10.

Nichols, G., Hirst, J.P., 1998. Alluvial fans and fluvial distributary system, Oligo-Miocene, northern Spine: contrasting processes and products. Journal of Sedimentary Research 68, 879-889.

Said, R., 1962. Geology of Egypt, Elsevier Publishing Company. Amsterdam - New York.

Said, R., 1981. The Geological evolution of the River Nile. Springer.

Said, R., 1990. Cenozoic. In Said, R. (ed.) The Geology of Egypt, 451-486. A.A. Balkema, Rotterdam, Brookfield.

Said, R., 1990a. Quaternary. In Said, R. (ed.) The Geology of Egypt, 487-507. A.A. Balkema, Rotterdam, Brookfield.

Said, R., 1993. The River Nile: Geology, Hydrology and Utilization. Elsevier, Amsterdam.

Sampsell, B., M. 2003. Geology of Egypt, Cairo - New York.

Schild, R., Wendorf, F., 2013. Early and middle Holocene paleoclimates in the South Western Desert of Egypt - The Word before unification. Studia Quaternaria 30 (2), 125-133.

Schlumberger, 1995. Geology of Egypt. In: Well Evaluation Conference. Egypt, Schlumberger Middle East, 1-64.

Shukri, N.M., Azer, N., 1952. The mineralogy of Pliocene and more recent sediments in the Faiyum. Institute du Desert Bulletin 2(1), 10-39.

Squyres C.H, Robert E, Handley R, List F.K, Pöhlmann G. 1987. Geological map of Egypt 1:500,000. NH 36 SW, Beni Suef. Conoco, Cairo.

Swelim, N., 1988. The Dry Moat of the Netjerykhet Complex. In Baines, J., Leahy, T.G.H., Shore, A.F. (eds.) Pyramid Studies and Other Essays Presented to I. E. S. Edwards. JARCE, $32-41$.

Swelim, N., 1991. Some remarks on the Great Rectangular Monuments of Middle Saqqara. MDAIK 47, 389 - 402.

Swelim, N., 2006. The Dry Moat, the South Rock Wall of the Inner South Chanel. In Czerny, E., Hunger, H., Melman, S., Schwab, A. (eds.) Timelines: Studies in Honour of Manfred Bietak, 363-376. Peeters, Louvain-la-Neuve.

Welc, F., 2011. The Third Dynasty open quarry west of the Netjerykhet pyramid complex (Saqqara). ÉtTrav., 24, 272-304.

Welc, F., Malata, E., Marks, L., Studencka, B., Olszewska, B., 2013. Preliminary remarks on enigmatic "White Casing Limestone" from Saqqara archaeological site in Egypt. Studia Quaternaria 30 (2), 115-123.

Welc, F., Marks, L., 2014. Climate change at the end of the Old Kingdom in Egypt around 4200 BP: New geoarchaeological evidence. Quaternary International 324, 124-133.

Welc, F., Mieszkowski, R., Trzciński, J., Kowalczyk, S., 2015. Western Section of the 'Dry Moat' Channel Surrounding Step Pyramid Complex in Saqqara in the Light of Ground-penetrating Radar Prospection. Archaeological Prospection, DOI: 10.1002/arp.1514.

Welc, F., Trzciński, J., 2013. Geology of the Site. In Myśliwiec, K. (ed.) Old Kingdom Structures between the Step Pyramid Complex and the Dry Moat. Part 2: Geology, Anthropology, Finds, Conservation, 323 - 343. Saqqara V Series, Warsaw.

Wendorf, F., Schild, R., Issawi, B., 1976. Prehistory of the Nile Valley. Elsevier Science and Technology Books, 1-404.

Woodward, J.C., Macklin, M.G., Krom, M.D., Williams, M.A.J., 2007. The Nile: evolution, Quaternary river environments and material fluxes. In Gupta, A. (ed.) Large Rivers: Geomorphol- 
ogy and Management, 261-291. John Wiley \& Sons, Ltd., Chichester.

Woronko, B., 2001. Significance of rounding and matting of quartz grain surfaces in the genetic interpretation of Quaternary sediments (Znaczenie analizy obtoczenia i zmatowienia powierzchni ziaren kwarcowych frakcji piaszczystej w interpretacji genetycznej osadów czwartorzędowych). In Mycielska-Dowgiałło, E., Rutkowski, J. (eds) Eolizacja osadów jako wskaźnik stratygraficzny czwartorzędu, 33-38. Pracownia Sedymentologiczna WGiSR UW, Warszawa (in Polish).

Woronko, B., Bujak, Ł., 2010. Microsculpture of quartz grain surfaces of the sand fractions from the preglacial sediments of the
Kozienice series as an indicator of transport and deposition conditions in the southern part of the Mazovian Lowland (Mikrorzeźba powierzchni ziaren kwarcowych frakcji piaszczystej osadów preglacjalnych serii kozienickiej jako wskaźnik warunków transportu i depozycji w południowej części Niziny Mazowieckiej). Biuletyn PIG 438, 137-154 (in Polish).

Youssef, M., Cherif, M.O., Boukhary, M., Mohamed, A.. 1984. Geological Studies on the Saqqara Area, Egypt. Neues Jahrbuchfür Geologie und Paleontologie Abhandlungen 168, $125-144$.

Zaki, R., 2007. Pleistocene evolution of the Nile Valley in northern Upper Egypt. Quaternary Science Reviews 26, 2883-2896. 